\title{
MAP2K1 Gene Rearrangement
}

National Cancer Institute

\section{Source}

National Cancer Institute. MAP2K1 Gene Rearrangement. NCI Thesaurus. Code C153254.

A molecular abnormality indicating rearrang ement of the MAP2K1 gene. 